\title{
Effect of Hydrolysis on Allergenicity and Sensory Quality of Whey Protein Concentrate
}

\author{
Smitha J. Lukose ${ }^{1}$, Narasimha Murthy ${ }^{2}$ and Anjum ${ }^{3 *}$ \\ ${ }^{1}$ Department of Dairy Chemistry, Kerala Veterinary and Animal Sciences University, \\ Thrissur, Kerala, India \\ ${ }^{2}$ Dairy Science College, Hebbal, Bengaluru-24, Karnataka, India \\ Karnataka Veterinary Animal and Fisheries Sciences University (KVAFSU), India \\ ${ }^{3}$ Department of Dairy Chemistry, Dairy SCienec College, KVAFSU, Hebbal, \\ Bengaluru-560024, Karnataka, India \\ *Corresponding author
}

\section{A B S T R A C T}

\section{Keywords \\ Dahi, Allergenicity, \\ Whey, Whey proteins concentrates, ELISA \\ Article Info \\ Accepted: \\ 20 April 2018 \\ Available Online: \\ 10 May 2018}

The extent of allergenicity of whey protein was revealed by inhibition ELISA using blood serum obtained from milk allergic infants. The effect of in vitro proteolysis on allergenicity and development of bitterness was studied using enzymes individually and in combination. Selective proteolysis of WPC was done to 3 and 5 per cent DH. A combination of enzymes was effective in reducing allergenicity at a lower DH. Sensory evaluation of hydrolysates was done to give bitterness scores. A hydrolysate with minimum bitterness and maximum reduction in allergenicity could be used to develop an ingredient for hypoallergenic cow milk formula.

\section{Introduction}

Although breast feeding has absolute priority in the nutrition of the newborn, infant formulae will continue to be needed to supplement or substitute for human milk as and when condition demands.

The modification of cow's milk for this purpose is accomplished by the addition of whey and whey proteins such as $\beta$ lactoglobulin, $\alpha$-lactalbumin or others become frequent allergens (Jost et al., 1987).
The incidence of food induced allergic disease in children has been estimated to be between $0.3-7.5 \%$. Immunologic mechanisms particularly $\operatorname{lgE}$ antibodies are responsible for the development of these food allergies in infancy and childhood (Harris et al., 1989; Robert and Zeiger, 1990). Cow's milk allergy is a hypersensitivity reaction to bovine milk proteins caused by immunological reaction (Bahna, 1980)

Among the whey proteins $\beta$-lactoglobulin is considered as the most potent allergen because 
it is absent in human milk and gives highest rate $(60 \%)$ of positive oral challenges in children with milk allergy (Asselin et al.,1989). Baldo et al., (1984) observed that the specificity of IgE antibodies in sera from infants with milk intolerance revealed decreasing hypersensitivity reactions to the individual proteins which were in the order of $\beta$-lactoglobulin $\alpha$-lactalburnin, caseins and bovine serum albumin.

The effects of enzymatic digestion of milk product were assessed by many researchers. Peptic and peptic-tryptic hydrolysis yielded breakdown products recognized by $\operatorname{IgE}$ antibodies (Haddad et al., 1989; Pahud et al., 1985) indicated that trypsin hydrolyzed whey protein $(4 \mathrm{~h})$ remained inactive in inducing oral sensitization in guinea pigs. However, such an extensive hydrolysis could result in production of bitter peptides (Clegg, 1977), Jost et al., (1987) indicated that combining selective hydrolysis by specific proteases with proceeding of subsequent heat treatment was promising in developing a hypoallergenic infant formula. Lahl and Grindstaff (1989) stated that with an optimal enzyme mixture, any source protein can be hydrolyzed or 'attacked' to obtain the optimal nutritional profile attainable from the substrate.

Lahl and Braun (1994) did hydrolysis under controlled condition to account for taste, solubility and certain physical properties of the hydrolysates. Enzymatic protein hydrolysates are usually characterized by a bitterness associated with terminal hydrophobic amino acids attached to peptides liberated during hydrolysis. Because of bitterness leading to poor palatability and increased cost, extensively hydrolyzed whey protein formulae are not suitable for routine use in a large population of allergic infants. Many companies have produced hypoallergenic formulae (Willerns et al., 1993) in which whey proteins were subjected for tryptic digestion with less amino acid degradation. Petrichek et al., (1972) stated that the enzyme specificity has some influence on bitterness of hydrolysates. However, they concluded that this field needs further investigations.

\section{Materials and Methods}

Enzymatic hydrolysis was performed on commercial whey protein concentrate $(70 \%$ protein) obtained from Mahaan proteins, New Delhi. The following products were purchased for the experiment. Enzymes, viz., trypsin (1:250 S.D. Fine Chemicals, Ltd), chymotryosin (40-60 units/mg protein, HIMEDIA). Sera of milk allergic infants (positive serum) and healthy infants (negative serum) was collected from Bowring hospital, Bangalore. All immune reagents were obtained from Genei, Bangalore.

\section{Enzymatic hydrolysis of whey protein concentrates}

Hydrolysis was performed on 4 per cent (on protein basis) solution of whey protein concentrate at $40^{\circ} \mathrm{C}$ and $\mathrm{pH} 8.0$ at an $\mathrm{E}$ : $\mathrm{S}$ ratio of 1:100 using enzymes individually and in combination. The hydrolysis was performed in triplicate for each reaction and time required to attain 3 and 5 per cent $\mathrm{DH}$ was noted in each case. Hydrolysis was arrested by heat treatment $\left(80^{\circ} \mathrm{C} / 15 \mathrm{~min}\right)$, cooled and were freeze dried.

\section{Characterization of whey protein hydrolysates}

The degree of hydrolysis (DH) is defined as the percentage of cleaved peptide bonds as assessed by tht $\mathrm{pH}$ stat technique described by Adler-Nissen (1986). In this method the volume of standard $\mathrm{NaOH}$ required to keep $\mathrm{pH}$ constant was directly converted to $\mathrm{DH}$ using the following formula 
$\mathrm{DH}=\mathrm{B} \times \mathrm{N}_{\mathrm{b}} \times 1 / \alpha \times 1 / \mathrm{MP} \times 1 /$ htot $\times 100 \%$

Where $\mathrm{b}=$ Base consumption in $\mathrm{ml}(\mathrm{NaOH})$; $\mathrm{N}_{\mathrm{b}}=$ Normality of the base $(0.1 \mathrm{~N}) ; \alpha=$ verage degree of dissociation of the $\alpha-\mathrm{NH}_{2}$ group; $\mathrm{MP}=$ Mass of protein in $\mathrm{g}$; htot= total number of peptide bonds in the protein substrate (meq/g protein).

\section{Allergenic analysis of hydrolysates}

Briefly, whey protein coated plates were first incubated with a pool of serum from patients allergic to milk and also from healthy infants; Optical density (OD) reading was noted to establish the allergenicity of WPC. Plates were coated with different concentration of whey to determine the concentration capable on inhibiting the reaction. This concentration $(1 \mathrm{mg} / \mathrm{ml})$ was used when hydrolyzed proteins were tested as inhibitors on subsequent experiments. The allerginity of various hydroysates were analyzed by their ability to inhibit the binding of human serum specific IgE antibodies to whey protein coated and results were expressed as the percentage reduction in allergenicity/ percentage inhibition for each hydrolysates using the following formula

(Blank-control) - (Blank-Sp. Inhibition X 100) Reduction in allergenicity $(\%)=$

(Balnk- Control)

\section{Sensory analysis}

2 per cent solution of WPC hydrolysates was prepared (Adler-Nissen, 1986) by hydrolyzing with 2 different enzymes and their combination were evaluated from bitterness on five points hedonic scale by five trained judges. A score from 1 to 5 was assigned to bitterness for each sample. The scores were 5 (no bitterness), 5-4 (slightly bitter), 4-3 (moderately bitter), 3-2 (strongly bitter), 2-1 (intensive bitterness).

\section{Results and Discussion}

The allergenicity of WPC was determined by measuring absorbance of sera for various dilutions and the optical density values are given in Table 1. The absorbance value is almost double when positive serum is used and this establishes the fact that whey proteins being allergenic forms antigen-antibody complex. The optimum antigen- antibody reactivity was observed at $1 \mathrm{mg} / \mathrm{ml}$ of protein concentration and at a serum of 1:50. The antigenicity may be due to sequential or surface epitopes (Speurgin et al., 1996). Conformational epitopes depend on the tertiary structure of $\beta$ - lactoglobulin is known (Burova et al., 1998) and the allergenic sites are in peptide presents between 25-107 and 108-145 amino acid regions (Otani et al., 1985). The poor digestibility of whey protein is also considered to be one of the reasons for their allergenicity (Boza et al., 1995).

Time required to obtain hydrolysates with 3 and 5 per cent DH is given in Table 2. Chymotrypsin is known to cleave bonds formed by involving amino acids with hydrophobic side chains of phenylalanine, tyrosine and tryptophan (Fersht, 1997).

Trypsin had specificity of bonds associated with the hydrophobid side chains of the amino acids lysine and arginine. From the table it is evident that chymotrysin is efficient in hydrolyzing WPC and as the concentration of chrymotrypsin is more in the combination efficiency is also improved. Pelissier (1984) stated that because of its high specificity and expected hydrolysate composition, chymotrypsin was chosen for enzymatic hydrolysis of whey proteins.

Table 3 reveals the reaction in allergenicity of WPC on hydrolysis. At 5 per cent DH trypsin was found to reduce allergnicity to the maximum extend of $77.74 \%$. 
Table.1 The allergenicity of WPC as determined by measuring absorbance of sera for various dilutions

\begin{tabular}{|c|c|c|c|c|}
\hline \multirow{3}{*}{$\begin{array}{c}\text { WPC } \\
\text { Concentration } \\
(\mathrm{mg} / \mathrm{ml})\end{array}$} & \multirow[t]{3}{*}{ Sera } & \multirow{2}{*}{\multicolumn{3}{|c|}{ Absorbance values (405 nm) }} \\
\hline & & & & ( \\
\hline & & $1: 25$ & $1: 50$ & $1: 100$ \\
\hline \multirow[t]{3}{*}{0.1} & Positive & 0.152 & 0.245 & 0.265 \\
\hline & Negative & 0.342 & 1.361 & 0.626 \\
\hline & $\begin{array}{l}\text { Difference in } \\
\text { Absorbance }\end{array}$ & 1.181 & 0.386 & 0.361 \\
\hline \multirow[t]{3}{*}{1.0} & Positive & 0.165 & 0.257 & 0.247 \\
\hline & Negative & 0.803 & 1.460 & 1.001 \\
\hline & $\begin{array}{l}\text { Difference in } \\
\text { Absorbance }\end{array}$ & 0.638 & 1.203 & 0.754 \\
\hline
\end{tabular}

Table.2 Enzymatic hydrolysis of WPC using enzymes and their combination

\begin{tabular}{|c|c|c|}
\hline $\begin{array}{c}\text { Enzyme/ Enzyme } \\
\text { Combination }\end{array}$ & $\mathbf{3}$ \% $\mathbf{D H}$ & $\mathbf{5} \% \mathbf{D H}$ \\
\hline Trypsin & 60 & 170 \\
Chymotrypsin & 10 & 23 \\
\hline Trypsin : Chymotrypsin & & \\
Ratio & 30 & 105 \\
$75: 25$ & 13 & 45 \\
$50: 50$ & 10 & 30 \\
$25: 75$ & & \\
\hline
\end{tabular}

DH- Degree of Hydrolysis

Table.3 Influence of enzymatic hydrolysis on reduction in allergenicity

\begin{tabular}{|c|c|c|c|c|c|c|}
\hline \multirow{2}{*}{$\begin{array}{c}\text { Enzyme/ } \\
\text { Enzyme } \\
\text { combination }\end{array}$} & \multicolumn{4}{|c|}{ Absorbance values $(405 \mathrm{~nm})$} & \multicolumn{2}{|c|}{$\begin{array}{c}\text { Reduction in } \\
\text { Allergenicity (\%) }\end{array}$} \\
\hline & Blank & Control & $3 \%$ DH & $5 \% \mathrm{DH}$ & $3 \% \mathrm{DH}$ & $5 \% \mathrm{DH}$ \\
\hline Trypsin & \multirow[t]{2}{*}{0.722} & \multirow[t]{2}{*}{0.340} & 0.469 & 0.637 & 33.76 & 77.74 \\
\hline Chymotrypsin & & & 0.439 & 0.497 & 25.90 & 41.10 \\
\hline \multicolumn{7}{|c|}{ Trypsin: chymotrypsin combination } \\
\hline $75: 25$ & 0.844 & 0.411 & 0.412 & 0.461 & 0.23 & 11.5 \\
\hline $50: 50$ & 1.085 & 0.370 & 0.459 & 0.635 & 12.5 & 37.0 \\
\hline $25: 75$ & 0.735 & 0.342 & 0.592 & 0.608 & 63.6 & 67.8 \\
\hline
\end{tabular}

DH- Degree of Hydrolysis 
Table.4 Sensory evaluation of WPC hydrolysates prepared by using different enzymes and their combination

\section{Enzyme/ Enzyme Combination}

Trypsin

Chymotrypsin

Trypsin: chymotrypsin

\section{Hedonic Scores}

3 \% DH 5 \% DH

4.50

1.70

3.46
3.97

1.11

2.48
Relative bitterness

$3 \% \mathrm{DH}$

Slightly bitter

Intensely bitter

Moderate bitter
$5 \% \mathrm{DH}$

Moderate bitter

Intensely bitter

Strongly bitter

DH- Degree of Hydrolysis

Schymidt and Poll (1991) based on their findings reported that the major allergen $\beta$ lactoglobulin is a good trypsin substrate. Asselin et al., (1989) stated that the allergenicity was reduced in hydrolysates compared to untreated proteins. Pahud et al., (1985) concluded that the powerful allergens in whey proteins lost its sensitizing capacity when hydrolyzed with trypsin. Even though chymotrypsin is better with respect to rate of hydrolysis it is less efficient in reducing allerghenicity. This may be attributed to the resistance of $\beta$-lactoglobulin to chymotryptic digestion as described by Reddy et al., (1988). Similar results were obtained for Schmidt and pool (1991) who reported that $\alpha$ lactalbumin was hydrolyzed easily and $\beta$ lactoglobulin more gradually by chymotrypsin. (At 3 per cent DH, combination was better with reduction in allergenicity of 63.6 per cent than the individual efficiency of enzymes. This is supported by Asselin et al., (1989) who stated that the specificity of enzymes should be complementary to form an effective combination and reported that the combination of chymotrypsin and trypsin significantly reduced allergenicity

Even though the rate of hydrolysis was more for chymotrypsin it is less efficient in reducing allergenicity. Based on their study Asselin et al., (1989) also reported that degree of hydrolysis is not the factor affecting allergenicity and the susceptibility of peptide bonds involved in the allergenic sites $\beta$ - lactoglobulin and $\alpha$-lactalbumin depend on the specific activates of the enzyme. From the amino acid sequence of $\beta$ - lactoglobulin it can be seen that the active site of the enzyme chymotrypsin in the region 25-107(antigenic site) is much lesser than that of trypsin.

The results of sensory evaluation of hydrolysates for bitterness and hence acceptability is given in Table 4 .

Sensory evaluation studies proved that threshold for bitter taste decreased with higher degree of hydrolysis. The potential level of bitterness was different for hydrolysates of different enzymes (Petrichek et al., 1972) and so can be related to the specificity of the enzyme and also depends on the degree of hydrolysis. This is supported by the findings of Ennis and Harper (1986) and other coworkers (Fox et al., 1982); Cowan, 1983; Kinsella 1982) who suggested that amino acid residues having hydrophobic side chains are implicated as determinants of better taste. The hydrolysates of chymotrypsin are intensely bitter whereas in some cases i.e., 5 per cent hydolysate of trypsin exhibited moderate degree of bitterness.

The requirement demanded in the formation of hydrolysates is that they should not have a bitter taste, should be hypoallergenic, should be low in free amino acids (Ney, 1979; Grimble et al., 1986; Otani et al., 1990). It is possible to reduce allergenicity by extensive hydrolysis but it imparts bitterness. However 
it is suggested that the moderate bitterness encountered in a partial hydrolysate can be masked if it is used in food formulation processes.

\section{References}

Asselin, A., Herbert, J. and Amiot, H., 1989, effects of in vitro proteolysis on the allergenicity of major whey proteins. Journal of Food Science. 54: 1037.

Bahna, S.L. and Heiner, D. L., 1980, "Allergies to milk". Grune and strates. New York. Pp. 1.

Baldo, B. A., 1984, Milk allergies. Australian. Journal of Dairy Technology, 9: 120.

Boza J.J., Augustin O.M., and Gril, A., 1995, Nutritional and antigenic characterization of an enzymatic whey protein hydrolysate. J. Agric. Food Chem., 43: 872.

Burova, T.V., Chiset, Y., Tran, V., Hartle, T., 1998, Role of free Cys 121 in stabilization of bovine $\beta$-lactoglobulin B. Protein eng., 11: 1065.

Clegg, M., 1977, dietary enzymatic hydrolysates of proteins. Biochemical aspects of new protein foods. FEBS, $11^{\text {th }}$ MEETING, Copenhagen. Pp. 109.

Cowan, W.D., 1983, The application of enzymes in industry. In Industrial Enzymology. The Nature Press, New York. Pp. 3 and 352.

Ennis, B. M. and Harper, W.J., 1986, Properties of spray -dried lactalbumin treated with a protease. Newzea. J. Dairy Sci. Tech, 21: 205.

Fersht, A., 1977, Enzyme structure and mechanisms; Freencn: 32 San Francisco, 18: 321.

Grimble, G.K., Keohane, P.P., Higgins, B.E., Kaminshki, M.V. and Silk, D.B.A., 1986. Effect of peptide chain length on amino acid and nitrogen absorption from two lactalbumin hydrolysates in the normal human jejunum. Clinical Science. 71:65.

Haddad, Z., Kalra, V. and Verma, 1989, IgE antibodies to peptic and peptic tryptic digests of $\beta$-lactoglobulin: significance in food hypersensitivity. Ann. Allergy., 42: 368.

Harris, M.C., Kolski, G.B., Campbell, D.E., Deuber, C., Marcus, M. and Doughlas, S.D., 1989, Ontogeny of the antibody response to cow milk proteins. Annal. Allergy., 11: 439.

Jost, R., Monti, J.C. and Pahud, J. J., 1987, Protein allergenicity and its reduction by technological means. Food Tech., 10:118.

Kinsella, J.E., 1982, In Food Proteins (Fox, P.F. and Condon, J, J., Eds). Applied Science Publishers, London. Pp.51.

Lahl, W.J and Grindstaff, D.A., 1989, Spices and seasonings: Hydrolyzed proteins. Proceedings of the $6^{\text {th }}$ SIFST symposium on food ingredients application, Status and Safety, 27-29 April 1989, Singapore, Singapore Institute of Food Science and Technology. Singapore. pp.51

Lahl, W.J., and Braun, S.D., 1994, Enzymatic production of proteins for food use. Food Tech., 10: 68.

Ney, K.H., Bitterness of peptides: amino acid composition and chain length. ACS symposium series., 115: 149.

Otani, H., Dong, X,Y., and Hosono, A, 1990, Preparation of low immunogenic peptides from milk casein. Milchwissenschaft., 45:217.

Otani, H., Morita, S. and Tokita, F., 1985, Japanese J. Zootech. Sci., 56:341

Pahud, J.J., Monti, J.C. and Jost, P., 1985, Allergenicity of whey proteins. Its modification by tryptic in vitro hydrolysis of the protein. J. Pediatr. Gastroenterol. Nutr., 4: 408

Pelissier, J.P., 1984, Proteolysis of caseins. Sciences des Aliments. 4:1. 
Petritschek, A., Lynen, F., Belitz, H-D., 1972, Lebensm. Wiss Technol., 5: 77.

Reddy, M., Kella, N.K.D., and Kinsella, J. 1988, Structural and conformational basis of the resistance of $\beta$-lactoglobulin to peptic and chymotrptic digestion. $\mathbf{J}$ Agric. Food Chem., 36; 737.

Schmidt, D.G. and Poll, J.K., 1991, enzymatic hydrolysis of $\alpha$-lactalbumin and $\beta$ lactoglobulin in buffer solutions by proteolytic enzymes. Neth. Milk dairy J., 45:225
Speurgin, P., Meuller, H., Walter, M., Schittz, E., Forster, J., 1996, Allergenic epitopes of bovine $\alpha$-s1 casein recognized by human IgE and IgG. Allergy., 51: 306

Willems, R., Duchateau, J., Magrez, P., Denis, R. and casimer, G., 1993, Influence of hypoallergenic milk formula on the incidence of early allergic manifestations in infants predisposed to atopic diseases. Annal. Allergy, 71:147.

Zeiger, R.S., 1990, Prevention of food allergy in infancy. Annal. Allergy., 65: 4.

\section{How to cite this article:}

Smitha J. Lukose, Narasimha Murthy and Anjum. 2018. Effect of Hydrolysis on Allergenicity and Sensory Quality of Whey Protein Concentrate. Int.J.Curr.Microbiol.App.Sci. 7(05): 28992905. doi: https://doi.org/10.20546/ijcmas.2018.705.338 